\title{
US urged to monitor some genetic tests
}

[WASHINGTON] Declaring that "the public is not being adequately protected", an expert panel last week recommended several broad of measures expanding government regulation of genetic testing. These include the establishment of a National Genetics Board and the monitoring of genetic tests considered to require "stringent scrutiny" by the Food and Drug Administration (FDA).

The panel also proposed that commercial laboratories be required to meet upgraded standards for genetic testing, or risk losing reimbursement by third-party payers, including huge government health programmes.

The recommendations, published last week in the Federal Register, come from the 15-member task force on genetic testing set up by the Working Group on the Ethical, Legal and Social Implications of Human Genome Research, established by the National Institutes of Health (NIH) and the Department of Energy.

The task force was established in 1995 to recommend steps to ensure the development and appropriate use of safe and effective genetic tests. A central recommendation is that some tests require "stringent scrutiny" throughout their development and marketing.

The suggested criteria used to decide whether stringent scrutiny is necessary would include: a test's potential to predict serious future disease in healthy people and their offspring; the absence of a confirmatory test; a test's uncertainty (the chances that a person with a positive test will not develop the disease); and the safety and effectiveness of known clinical interventions.

These criteria seem aimed in particular at tests being marketed by companies such as Myriad Genetics of Salt Lake City, Utah, which last October introduced full sequence commercial testing of $B R C A 1$ and $B R C A 2$ genes, mutations of which predispose women to breast and ovarian cancer.

Tests requiring stringent scrutiny would be subject to more careful review at several stages. They would be reviewed more carefully by institutional review boards, the local committees charged with ensuring that human subjects receive protection in experimental protocols.

They would also require pre-market approval by the FDA, whether sold as kits or carried out in-house. In-house tests are not at present monitored by the FDA, and virtually all genetic tests - including Myriad's - are being developed and marketed as such.

Separately, the task force recommends that Donna Shalala, the Health and Human Services Secretary, should create within her office an Advisory Committee on Genetics and Public Policy to develop "coordinated and consistent" genetic testing policies throughout the department. That would include the NIH, the Centers for Disease Control and Prevention and the FDA.

This advisory committee would in turn recommend that Shalala establish a National Genetics Board of consumers, physicians, insurers and scientists. Its duties would include fully developing the 'stringent scrutiny' standard, and possibly reviewing and approving all experimental protocols for tests requiring such scrutiny, as a condition of their receiving federal funding.

If the FDA were to regulate in-house tests, then non-federally funded test developers would also be obliged, under current FDA regulations, to have protocols requiring stringent scrutiny approved by local institutional review boards, the task force says.

In the area of laboratory quality, the recommendations would "address the deficiencies" in monitoring genetic tests of the 1988 Clinical Laboratory Improvement Amendments - the law that established current quality standards for commercial laboratories.

The task force calls for the setting-up under that law of a national accreditation programme to ensure genetic testing quality, with third-party payers encouraged to reimburse only accredited laboratories.

Patricia Barr, a lawyer and task force member who also represents the National Breast Cancer Coalition, says that the recommendations will, if accepted, ensure "a level of coordination and regulation of genetic testing that is not taking place today".
Wayne Grody, a task force member who is a medical geneticist at the University of California, Los Angeles, says: "The most important recommendation is that there be some overarching body within Health and Human Services that would monitor and advise on genetic testing."

But the recommendations - particularly the proposed National Genetics Board and the call for FDA monitoring - are already drawing fire from academic and industry critics. Academics fear that the creation of a National Genetics Board could slow down the grants process.

Francis Collins, director of the National Human Genome Research Institute, declined to comment last week, but voiced concern during a task force meeting last December. "If this national board is slow to review and respond to protocols you may hear a hue and a cry and justifiably so," he said then.

Others say that involving the FDA could deal a fatal blow to small companies that develop tests. "It's going to take genetics back to the dark ages" if companies marketing inhouse tests have to go through the FDA, says one industry critic. Only large companies with deep pockets could afford to develop tests in such circumstances, says the critic.

Comments on the panel's recommendations may be e-mailed by 10 March to tfgt-a@welchlink.welch.jhu.edu, and will then be finalized. Comments will be discussed at a meeting on 17-18 March in Baltimore, Maryland, after which final recommendations will be issued. Meredith Wadman

\section{Russian budget falls short of 'legal level'}

[Moscow] The State Duma - the lower chamber of the Russian parliament - last week adopted a budget for 1997 allocating 15.4 thousand billion roubles (about US $\$ 2.5$ billion), representing 2.9 per cent of all state spending, to research and development.

This contrasts with a commitment to give research at least four per cent of state spending contained in the so-called 'science law' signed by President Boris Yeltsin last August. The difference between the two figures is attributed to a lack of coordination between the executive and legislative branches of government.

"The Duma's law was prepared at the time when the government had already fixed all the major budget parameters," says Mikhail Glubokovsky, deputy chairman of the Duma's committee on science and education.

Glubokovsky's committee is keen to see the immediate implementation of a Duma resolution that the state should repay to research institutions the sum of 2.7 thousand billion roubles (US\$450 million) which remains outstanding from last year's budget.

Vladimir Fortov, chairman of the state committee on science and technology, said that "the Russian science ship is in low water since the state spends on it

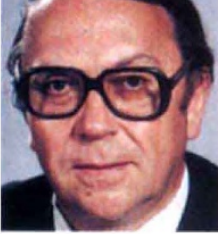
only 0.3 per cent of gross national product". Fortov, who is also vicepresident of the Russian Academy of Sciences, said that this was because, Fortov: bemoans although it had been low science spend. planned to allocate 0.5 per cent of gross national product to research, only 60 per cent of this had been paid. He added that financing is taking place on a weekto-week basis, preventing plans from being made "even a month ahead".

Speaking at a meeting of the scientific council of the Joint International Nuclear Institute in Dubna, Fortov expressed the hope that some of the international credits being received by Russia should be used to support a few large high-technology projects. CarlLevitin 